\title{
Japan builds on global lead in nanotechnology
}

Tokyo. Despite the impact of the recession on overall research spending in Japan, one area in which efforts are continuing to expand rapidly is quantum science and technology, the study and application of nanoscale phenomena. Two reasons behind this enthusiasm are Japan's mastery of device fabrication - and its success in the commercial exploitation of the results.

In the West, thin-film growth techniques such as molecular beam epitaxy and metalorganic chemical vapour deposition remain exotic laboratory procedures. But in Japan, companies such as Fujitsu and Sony have already moved to the production line, for example to make quantum-well semiconductor lasers for compact disc player pickups and high electron mobility transistors for amplifiers for consumer satellite dishes.

Keen to build on this success, the Ministry of International Trade and Industry (MITI) earlier this month put in a bid for funds with the government that would more than double support for its new Ångstrom Technology Partnership project from US\$10 million to US\$22.4 million next year.

Two other government agencies are also pouring money into such research, and the private sector continues to back work on nanoscale electronics and photonics.

The Angstrom project began in April 1993, and will run for ten years at an overall cost of $\$ 250$ million. The project differs from previous large-scale MITI initiatives in that it includes many researchers from universities, who come under the jurisdiction of the Ministry of Education, Science

and Culture (MESC), reflecting MITI's desire to stimulate a more open government research system (see Nature 371, 3; 1994).

Another difference is that, of 30 corporate participants, six are non-Japanese companies, five based in the United States and one (Samsung Electronics) in South Korea.

The extra money will help to pay for new equipment at the Joint Research Center for Atom Technology, the project's base in Tsukuba. This includes two supercomputers: a conventional vector processor, made by Fujitsu, and a massively parallel CM5E made by Thinking Machines of the United States.

At present, most research focuses on fundamental rather than applied issues. In particular, scientists are looking at ways of confining electrons and photons to one and zero dimensions in devices such as quantum wires and dots. To produce such devices, they need to develop techniques for fabricating structures whose smallest dimension is less than 10 nanometres.

At Tokyo University's Institute of Industrial Science, for example, Yasuhiko Arakawa has grown gallium arsenide quantum wires less than $10 \mathrm{~nm}$ wide, and quantum dots as small as $7 \mathrm{~nm}$. His ultimate goal is to build single-electron devices.

Arakawa has had little difficulty with funding. From 1987 until March this year, his group was sponsored by MESC and private companies. Now, and up to 1997 , government funding comes from a successor project, Quantum Coherent Electronics.

Arakawa's former mentor, Hiroyuki

\section{Prime Minister's Office}

\section{RIKEN}

International Frontier Materials Professor Sugano

Sakaki Quantum Transition Project

Professor Sakaki: 1994-99 Professor Metz UCSB
STA

JRDC

Aono Atomcraft Project Dr. Aono 1989-94

Yamamoto Quantum Functuation Project Professor Yamamoto 1993-98

\section{Ministry of Education,}

Science \& Culture (MESC)

Single Electron Charging

Professor Kobayashi 1993-95
Quantum Coherence Electronics Professor Ando 1994-97
Ministry of International Trade \& Industry (MITI)

\section{FED Assoc}

Angström Technology 1992-2002
Quantum Functional Devices 1991-2000
Fujitsu

Motorola
Hitachi

NEC

Sony
Sakaki, is also about to embark on a second quantum device research project. For the next five years, the Research \& Development Corporation of Japan - an offshoot of Japan's Science and Technology Agency will fund Quantum Transition, a collaborative project between Sakaki's group at Tokyo University and the Center for Quantized Electronic Structures (QUEST) at the University of California, Santa Barbara.

JRDC's first foray into international collaborations was a programme called Atom Arrangement-Design and Control for New Materials, which began in 1990 . This fiveyear, $£ 5$-million project brings together Japanese researchers with counterparts at the universities of Cambridge and London.

A third international JRDC quantum initiative is Yamamoto Quantum Fluctuation, a five-year, \$17-million ERATO project that began last year. Its leader is Yoshihisa Yamamoto, a laser physicist from Nippon Telegraph \& Telephone (NTT) who is now a professor of electrical engineering at Stanford University in California. The project combines talents from Yamamoto's former and current research groups.

According to Seigo Tarucha, a supervisor at NTT's Basic Research Laboratories in Atsugi, about a hundred of the company's researchers are working on quantum phenomena. The emphasis is on techniques for epitaxial growth and device fabrication.

Across the road at Fujitsu's Atsugi laboratory, Naoki Yokoyama and his group have been working on resonant tunnelling transistors for almost ten years. Their ultimate aim is to produce extremely high density devices (in the 10 gigabit class).

Fujitsu's work is the furthest along of six investigations into new device concepts supported under MITI's Quantum Functional Devices project, which runs from 1991 to 2000. Other partcipants include Hitachi, Matsushita, NEC and Sony. One surprise is the participation of researchers at the laboratory in Phoenix, Arizona, of an American company, Motorola. Motorola is one of the last non-Japanese companies still active in quantum device research. In the United States, IBM and Bellcore have disbanded their formerly world-leading compound semiconductor groups; and in Europe, where Philips had the main research group, activity outside universities has largely ceased.

In contrast, Japanese companies are continuing to work in the field. Hitachi, for example, has between 70 and 80 researchers for work on quantum topics. Ten are currently working at a laboratory in Cambridge, England, but most are based at the company's Central Research Laboratories in Tokyo. The emphasis, however, is shifting from basic to applied research. "For Japanese industry, it is difficult to carry out basic research because of the recession," says 
Eiichi Maruyama, the former Hitachi research manager who heads the MITI Ångstrom Technology Partnership. That is why, Maruyama claims, companies welcome MITI's initiative.

Some Japanese researchers, however, are concerned about the large amounts of government funding going into the field. "The presence of so many projects is not a good sign," says Hiroyuki Sakaki. "Particularly for younger researchers, it may be more intelligent to look for some newer subject one that will attract people in ten years' time."

Bob Johnstone

\section{Latin America pleads for more technology}

São Paulo. The heads of state and government of Latin American and Caribbean countries last week issued a joint plea to industrialized countries not to impose obstacles on the transfer of the technologies they need to modernize their economies and adjust to the pressures of international competition.

They also said, in addition to more access to Western technologies, they would like to participate in the development of new technology as "producers and consumers" of knowledge. But, although discussing the prospects for greater regional cooperation in science and technology, no new measures were agreed to. The only concrete result of such diplomatic promises is an Argentinian-Brazilian biotechnology centre created in the 1980s.

The heads of state were in Rio de Janeiro for the eighth meeting of the so-called Rio Group, and will present a document listing their conclusions to the American Summit in Miami next December. Among other things, the document says that "national and international controls for the transfer of dual technologies [those with both civilian and military applications] should not hinder the access to goods and advanced technologies of pacific use with the aim of development".

The heads of state point out that their region was the first to commit itself, through the Treaty of Tlatelolco, to remaining free of nuclear and other weapons of mass destruction. But the document is not intended to refer only to the uses of nuclear energy. Brazil, for example, feels that it has been treated unfairly over its Satellite Vehicle Launcher, which the United States fears may be converted into a ballistic missile.

A boycott by Western nations has meant that Brazil has turned to China for help with the development of satellites. And last week (15 September) Brazil signed a nuclear energy agreement with Russia that may lead to Russian assistance for Brazilian reactors.

Ricardo Bonalume Neto

- The former head of India's Atomic Energy Commission, M. R. Sirinivana, last week claimed that India possessed nuclear weapons, which were being kept as a "protection" against Pakistan.

\section{Pasteur Institute climbs out of rags and into riches}

Paris. Next year, the centenary of the death of Louis Pasteur, has been designated the "year of Pasteur" by UNESCO. It comes just as an internal review of the activities of the Pasteur Institute in Paris shows remarkable growth over the past six years, due mainly to large increases in its income from patents and commercial services, and legacies and donations.

Both trends would have pleased Pasteur himself, who considered applied and fundamental research as equally important, "linked as a fruit to its tree". Pasteur also began the institute's tradition of fund raising; it was founded in 1887 with FFr2 million - around FFr50 million (US\$9.4 million) at today's values - raised in this way.

The institute's budget has grown from FFr550 million in 1988 to FFr860 million last year a growth of 55 per cent in five years. According to the review, income from industry grew from FFr 70 million to FFr160 million over this period, and from commercial services such as the preparation of monoclonal antibodies from FFr53 million to FFr 70 million. As a result, their combined share of the total budget has increased from 20.5 to 26 per cent.

Legacies and donations, the Pasteur's other traditional source of income, increased from 18.8 to 27.2 per cent of the total budget. Legacies alone accounted for FFr190 million in 1993; one donor, the British company Virgin, raised FFr12 million for AIDS research at the institute through the sale of a compact disc recorded by a number of prominent singers.

As a result of the growth in Pasteur's own resources, even though government funding increased by 10 per cent between 1988 and 1993 , its share of the total budget has dropped from 47 to 36 per cent. The new figures therefore represent a turnaround in Pasteur's long struggle to generate income and regain some of the independence it lost in 1965 when a financial crisis forced it to turn to the state for support

At the time, Général Charles De Gaulle, the then French president, did not hesitate to help an institute that he once called "as untouchable as the Eiffel Tower". But his government made its support conditional on Pasteur separating its research from its commercial and industrial activities.

Pasteur's subsequent transition from a cottage industry into a one responsible for joint ventures with international companies has not been easy. In 1972, for example, it created Institut Pasteur Production (IPP). Sanofi, a subsidiary of the French oil company Elf, took a 35 per cent stake in IPP in 1976 , but the company was still losing money in 1984. Profitability came only after Pasteur handed over control of its vaccines and serums business to Institut Mérieux (a subsidiary of the Rhône-Poulenc group), and of its diagnostics business to Sanofi.

Pasteur-Mérieux Vaccines and Serums is now the world leader in the \$2-billion vaccine market, with three-quarters of its sales outside France (last year the company distributed a billion doses of vaccines) Pasteur-Sanofi Diagnostics ranks fifteenth in the world market, with sales of FFr1.4 billion last year.

Much of Pasteur's recent success has come from its aggressive patenting policy. Income has tripled since 1988 and risen from 9 to 18 per cent of the total budget. The institute now has 254 patents, and gives a

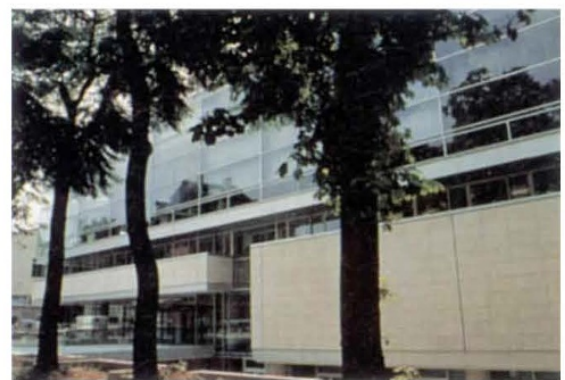

The new FF 110 million scientific information centre which is being opened at the Institut Pasteur in Paris next week by Edoaurd Balladur, the French prime minister. Financed from a FFr270 million legacy of jewels from the Duchess of Windsor, the centre will hold the 30,000 books and volumes of 2,500 journals of the existing library, one of the finest collections in microbiology.

share of royalties to individual researchers, although it recently fixed an annual ceiling of FFr 300,000 to prevent some researchers earning too much more than others.

All of these results have come as a boost to the standing of Maxine Schwartz, who was reelected earlier this year as director of the institute for a second six-year term. The internal review covered his first term of office, and during this period the institute also expanded and reoriented its research activities.

Concrete evidence of this growth includes a large new building for research on AIDS and retroviruses, the most visible evidence of the institute's massive investment in an area that involves a tenth of its researchers and its budget. Next week will see the opening of a FFr110-million hightechnology scientific information centre which symbolizes the institute's desire to increase its attractiveness to both French and foreign scientists.

Declan Butler 